\title{
Analysing Socio-Demographic Differences in Access and Use of ICTs in Nigeria Using the Capability Approach
}

\author{
Wole Michael Olatokun \\ Department of Library and Information Studies, \\ University of Botswana, Gaborone, Botswana
}

\author{
wole.olatokun@mopipi.ub.bw
}

\begin{abstract}
This paper presents disaggregated survey data on ICT ownership, access to public ICT facilities, capabilities and actual use of ICTs in two locations in a Nigerian municipality. The study analysed socio-demographic differences in access and use of ICTs using Sen's capability approach. Survey research approach was adopted. The locations were a rural and an urban community. The population of the study comprised 500 respondents selected from the two locations. The two locations were intentionally selected with a view to ensuring rural versus urban data comparisons. A structured questionnaire was the data collection instrument adopted. Chi-square analysis was used to determine the significant factors affecting people's access and use of ICTs. The result was cross tabulated against the socio-demographic characteristics of the people in the two locations. Findings revealed that there was a gender digital divide among the respondents in the two locations as well as rural-urban divide. It was also found that both male and female respondents in the two locations had access to all the ICT facilities surveyed, some in the ir homes and others in public places such as church, cyber café, working places, friend's place, etc. However, most of the respondents in the rural community were reported to be able to use landline telephones more than cell phones. In the two locations, the respondents were capable of using radio and television very well. Female respondents in both locations were able to use landline telephones more than their male counterparts but the males were capable of using other facilities more than the female respondents. This was chiefly due to the fact that the male respondents in the two locations were more educated than the females. The young set of respondents was also capable of using ICTs more than the older people. Based on the findings, it was recommended that the government need to evolve policies aimed at bridging the digital divide particularly increasing ICT penetration in both rural and urban areas.
\end{abstract}

Keywords: Access, Capability Approach, Digital divide Information and Communication Technologies, Socio-demographic differences, Use, Nigeria

Material published as part of this publication, either on-line or in print, is copy righted by the Informing Science Institute. Permission to make digital or paper copy of part or all of these works for personal or classroom use is granted without fee provided that the copies are not made or distributed for profit or commercial advantage AND that copies 1) bear this notice in full and 2) give the full citation on the first page. It is permissible to abstract these works so long as cred it is given. To copy in all other cases or to republish or to post on a server or to redistribute to lists requires specific permission and payment of a fee. Contact Publisher@InformingScience.org to request redistribution permission.

\section{Introduction}

The impact of the development of the information soc iety and especially the impact of Information and Communication Technologies (ICTs) on spatial development is now a question of discussion. One reason for this is probably simply the fact that, as Moss (2000) argued, we do not understand how these 
technologies will shape the growth of development. Modern ICTs are newcomers and their application is still in the early stage, although rapidly increasing. Within half a century, they have changed the world and affected millions of lives in ways that no one could have ever foreseen or imagined. They have also changed the nature of work we do, the range of occupations and skills requirements, making it necessary for workers to acquire a broader, add more adaptable knowledge base etc. They are transforming the ways in which we learn, communicate, do business, enjoy our leisure and live our everyday lives. ICTs defining characteristics are their capacity to harness, access and apply information and diffuse know ledge at electronic speed to all types of human activities and endeavors, thereby giving rise to contemporary know ledge-based economies and societies. According to Sood (2002), ICTs present an unprecedented opportunity to make new knowledge, services and opportunities available in underserved areas. In 1995 and 1997, the United Nations Commission on Sc ience and Technology for Development (UNCSTD) also investigated the benefits and risks of ICTs and the results showed many instances (such as in health, education, banking, etc.) where its use affords widespread social and economic benefits (World Bank, 1998). The growth and development of ICT has led to their wide diffusion and application, thus increasing their economic and social impact. The OECD (2007) undertook a wide range of activities aimed at improving our understanding of how ICTs contribute to sustainable economic growth and social well-being and their role in the shift toward know ledge-based societies. It has therefore become imperative to access and use ICTs everywhere especially in a developing country such as Nigeria.

ITU (2003) had noted that there are digital divide in the access and use of ICTs because of sociocultural and economic factors (including gender, income, age, education) around the world. That is, there are gaps in access to and use of ICT among sex (male and female), age (old and young), education (skilled and unskilled), income level (high income earners and low income earners), location (rural and urban) etc. This study therefore seeks to find out whether there are sociodemographic differences that really affect access and use of ICTs in Nigeria using Sen's (1992, 1993, 1999) capability approach. This is to say that despite people being effectively able to use ICTs (i.e. their capabilities); there are socio-demographic (individual) differences in the access and use of these technologies along the dimensions of age, sex, location, education, income etc and these differences tend to affect freedom of use in the aspect of knowledge/experience to use ICTs. The study aimed at providing answers to the following research questions:

1. What are the real opportunities that are available for people to access ICTs in Erunmu and Bodija communities?

2. What are the characteristics of people who use and not use ICTs facilities in the two locations?

3. What are their reasons or objectives for using ICTs in the two locations?

4. How has the socio-demographic composition of people affected access to and use of ICTs in the two locations?

5. What are their capabilities of using ICTs despite having freedom of use?

Although, lots of studies (Alampay, 2006a; Choike organization, 2004; Colle \& Roman 2002) have been carried out on access and use of ICTs, studies of socio-demographic differences in the access and use of ICTs in Nigeria using the capability approach are lacking. A study of this kind is justified in a number of ways especially in a developing country like Nigeria. First, it will help in determining the real opportunities available for the people of surveyed locations to access ICTs. Second, it will help to identify the characteristics of people who use and do not use ICT facilities and their reasons for using or not using them. Finally, it will reveal the existence and dimensions of possible socio-demographic differences in the access and use of ICTs in the loca- 
tions; which will thereby help in bridging the digital divide in the access and use of ICTs through informed ICT policies.

\section{Review of Literature}

Since the majority of the world population had remained untouched by the IT revolution, concern was expressed that the huge potential of ICTs for advancing development of the developing economies has not been fully captured, thus manifesting the "digital divide". To bridge the digital divide, it is imperative to put ICTs firmly in the service of development, for which urgent and concerted action at the national, regional and international levels is required. The digital divide may be defined as inequality in the ICTs network infrastructure and distribution of the IT knowledge, skills and resources necessary to access online services and information among different sections of a modern society (UNESCAP, 2005). It could also mean inequalities in access to and utilization of ICTs, communication infrastructure, computer availability, Internet access and availability of alternative access, e.g. through cable, satellite and digital TVs. UNESCAP (2005) set some indicators to assess the nature and extent of digital divide including: comparison of personal computer/Internet access with family structure, role of age and gender, ethnic divide (cultural divide), language (on the Internet), urban/rural divide, firm size, business/industry sector, cable/satellite access, digital TV, mobile telephony as a potential route for Internet access. This led to the Digital Access Index (DAI) designed by ITU (2003) to measure the overall ability of individuals in a country to access and use ICTs. The DAI is built around four fundamental vectors that impact a country's ability to access ICTs: infrastructure, affordability, know ledge and quality and actual usage of ICTs. The DAI has been calculated for 181 economies where European countries were among the highest ranked. It allowed countries to see how they compare to peers and their relative strengths and weaknesses. It also provided a transparent and globally measurable way of tracking progress towards improving access to ICTs.

In 2003, ITU conducted a study which showed that over half of the households in the USA own computers, compared to less than 1\% in Africa (ITU, 2003). About 77 millions of computers in the USA have valid Internet addresses while a country like Chad has fewer than ten computers linked to the Internet. Over time, this divis ion between countries has increased, even as all countries have steadily increased their Internet users. In other communication technologies aside computers and the Internet, the divide is significant but not as great. Nonetheless, it was estimated that $80 \%$ of the people in the world have never made a phone call (Digital Dividends, 2001). Even though inequalities in access to ICTs are most apparent among countries, there are also inequalities within countries where there is information under class. In the USA, the least connected households are those with low income, B lack, Native American, the unemployed, the disabled, single parent households, those with little education, those residing in the rural areas. The technology gap is not a reflection of the choices made by individual households, but poor neighbourhoods, and some rural communities lack the necessary infrastructure available in affluent and more populated areas (Benton Foundations, 1998). The digital divide in developed countries (e.g. New Zealand) equally reflects existing disparities in race, income and location (Doczi, 2000). This divide may be among different sectors of the economy; households, education etc. The digital divide among all these sectors appears to mainly depend on two factors, viz. income and education. The higher the incomes and the level of education the higher it is that more number of individuals will have access to ICTs. Access to and use of ICTs is to be viewed as a means for improving the quality of life, and not as ends in themselves. This creates the need for working towards achieving certain goals and benchmarks for selected indicators, their monitoring and measurement and application of statistical tools to track progress, analyze and assess the benefits and to enable comparison among economies. 


\section{Access to ICTs}

Access can be defined in terms of physical access to an ICT device. The simplest, though most limited, way of thinking about ICT access is in terms of ownership of a device (Warschauer, 2004). Ownership, however, is not the only way people gain access to ICTs. Even if a person does not own a particular ICT, sometimes they can access one through another member of the household, a friend or a neighbour, through the work place, or in public places. Hence, it was important to investigate accessibility of ICTs through these alternative means. According to Alampay (2006a), access can be quantified at different levels: the individual, the household, and the community. Measures in terms of individuals include indicators such as ICTs per 100 inhabitants, and the percentage of the population that uses an ICT. It can also be used to measure availability of ICTs in homes to determine the level of universal service. Community indicators measure the availability of service in population centres, such as the number of municipalities or villages with telephone service (ITU, 2003). A different criterion was necessary in evaluating a policy from the client perspective. According to Alampay (2006a) universal access cannot be collected in national statistics; therefore, she conducted a separate household survey at the community level. This is done to determine the relationship that exist among specific variables and can serve as feedback in improving the delivery of services to the underserved in society.

In the view of Black (2002), an alternative approach for ICTs access is the community ownership model that combines community-owned ICTs enterprises with the new wave of wireless and related technologies. This approach can greatly reduce costs and maximize the value-added of community resources, enabling the emergence of a new business model that is both more economically sustainable and more empowering than anything else available. Furthermore, the impact on development is greater as local needs are addressed more effectively, while they act as a community catalyst and as a support for a range of other development activities. Certain advantages of a community-ownership model have long been demonstrated in infrastructure projects, in both developed and developing countries. In poorer countries, local community control and partic ipation is widely recognized as being critical to the success of ICT projects such as telecentres and application development

Choike Organisation (2004) noted that technological innovations, especially w ireless technology, considerably reinforce the potential of community owned enterprises to help solve the access issue. This is due to their low level of initial investment and scalability, the ir relatively simple technical deployment, their low-cost and open standards, and their adaptability to voice and data requirements. In the opinion of Robeyns (2005), open source software is now developed for fullscale wireless networks. The viability of the community ownership approach, although, depends on two pressing needs: access to finance and an enabling environment at national and local level. These are essential to ensure long-term sustainability from the community itself. Regulatory obstacles have long been the major barrier to progress in many areas of ICTs development. Limitations of one-size-fits-all liberalization of the sector, and the failure of one-operator-does-all schema is leading the debate at the World Summit on the Information Society (WSIS) beyond binary oppositions and into new and less dogmatic territory (Choike organization, 2004).

On the contrary in Nigeria, universal access goals are defined in terms of local exchange carrier service, public calling office and payphone coverage, cellular service coverage and broadband internet services. Evidence suggests, however, that these traditional methods for measuring access may be inadequate (ITU, 2003). It is mis leading since it does not reflect the different sociodemographic composition of the country or state. 


\section{Theoretical Framework}

The capability approach is a broad normative framework for the evaluation of individual wellbeing and social arrangements, the design of policies and proposals about social change in society. The approach is used in a wide range of fields, most prominently in development thinking, welfare economics, social policy and political philosophy. It can be used to evaluate a wide variety of aspects of people's well-being, such as individual well-being, inequality and poverty. The core characteristic of the capability approach is its focus on what people are effectively able to do and to be, that is, on their capabilities. This contrasts with philosophical approaches that concentrate on people's happiness or desire-fulfillment, or on theoretical and practical approaches that concentrate on income, expenditures, consumption or basic needs fulfillment. A focus on people's capabilities in the choice of development policies makes a profound theoretical difference, and leads to quite different policies compared to neo-liberalis $m$ and utilitarian policy prescriptions. Some aspects of the capability approach can be traced back to, among others, Aristotle, Adam Smith, John Stuart Mill and Karl Marx (see Nussbaum, 2000; Sen 1993, 1999), but the approach in its present form has been pioneered by the economist and philosopher Amartya Sen (1992, 1993, 1999). "The capability approach to a person's advantage is concerned with evaluating it in terms of his or her actual ability to achieve various valuable functioning as a part of living. The corresponding approach to social advantage -for aggregative appraisal as well as for the choice of institutions and policy - takes the set of individual capabilities as constituting an indispensable and central part of the relevant informational base of such evaluation" (Sen, 1993, p. 30).

The main ingredients of the capability approach are functionings and capabilities, as is depicted in Figure 1 (Robeyns, 2000, p. 5)

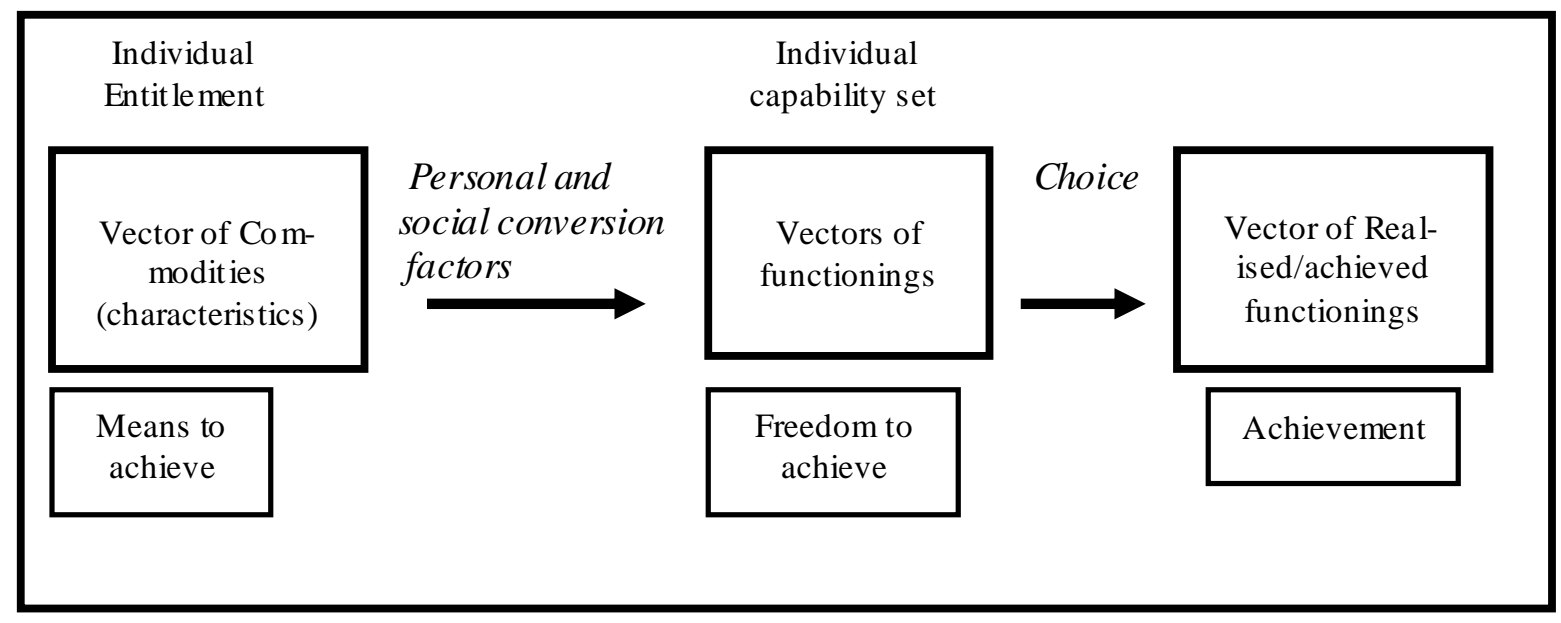

Figure 1: Sen's Capability Approach (Source: Robeyns, 2000, p. 5)

Functionings are then "beings and doings" of a person, whereas a person's capability is "the various combinations of functionings that a person can achieve. A functioning is an achievement of a person: what she or he manages to do or be. It reflects, as it were, a part of the "state" of that person (Sen, 1985, p 10. Achieving a functioning (e.g. being adequately nourished) with a given bundle of commodities (e.g. bread or rice) depends on a range of personal and social factors (e.g. metabolic rates, body size, age, gender, activity levels, health, access to medical services, nutritional know ledge and education, climatic conditions, etc.) A functioning therefore refers to the use a person makes of the commodities at his or her command or disposal. 
Capability is thus a set of vectors of functionings, reflecting the person's freedom to lead one type of life or another (Sen, 1992, p. 40). A capability reflects a person's ability to achieve a given functioning ('doing' or 'being'). For example, a person may have the ability to avoid hunger, but may choose to fast or go on hunger strike instead. Capabilities are notions of freedom, in the positive sense: what real opportunities you have regarding the life you may lead" (Sen, 1987, p. 36)

In operationalizing Sen's capability approach in this study, the conceptual framework of Alampay (2006b) was adopted as presented in Figure 2.

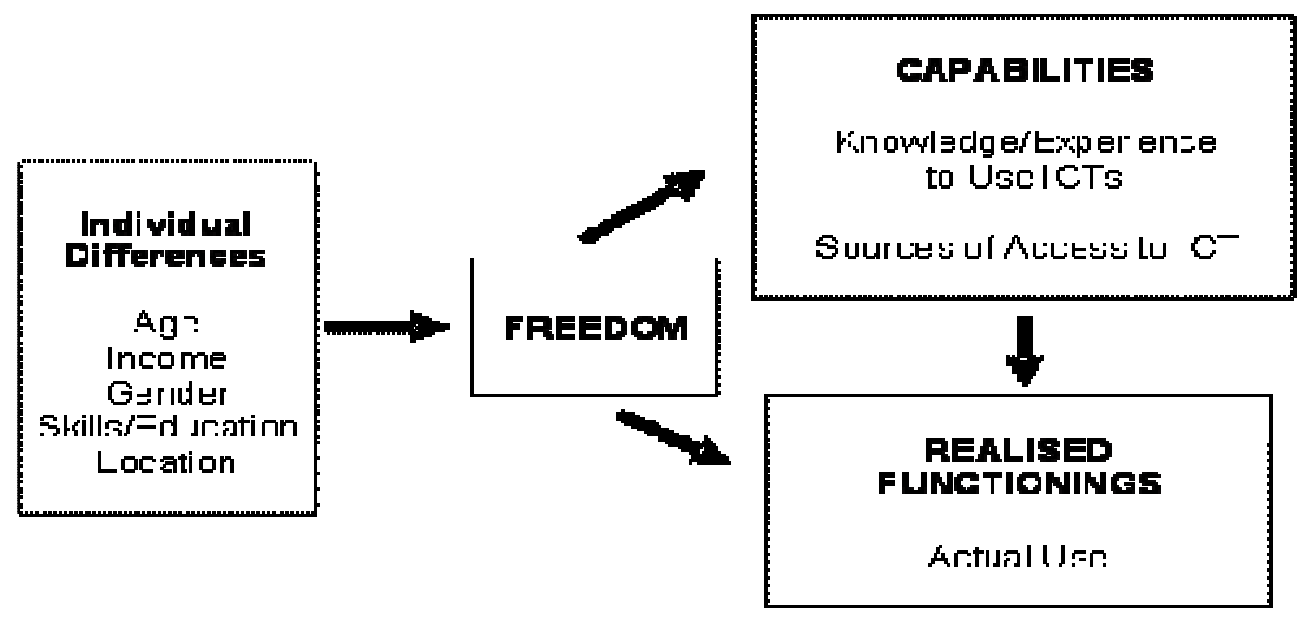

Figure 2: The Capability Approach Applied to Access to ICTs (Source: Alampay, 2006b)

\section{Individual Differences in Capabilities and Opportunities}

According to Alampay (2006b), while access to a basic good is a prerequisite to use, the capability approach says that individual differences, capabilities and choice play a role on whether people make use of these goods, how they apply them, and how they are valued. Unfortunately, traditional measurement of ICT access still does not monitor the variations in the amounts and functions of use of ICT resources by different people. Since Sen (1999) argues that people have different ways of transforming the same bundle of goods into opportunities for achieving their plans in life, it is important to understand the complex nature of what restricts effective demand for them by ordinary people (Cariño, 2003).Among the factors that are often cited as having an influence on ICT use are: gender; income; level of education and skills; age; and the available infrastructure in an area (Madhusudan, 2002; UNDP, 2001; World Bank, 1998). Since these factors are expected to affect people's ability to access and use ICTs, this study looked at gender, age, education, socio-economic income and location as variables that may influence the use of ICTs.

\section{Ownership, Access and Use}

According to ITU (2003, p. 12) "ownership/subscription" means an individual possesses an ICT device. "Access" means an individual could utilize an ICT because it is available, but may not necessarily be doing so, while "use" means a person is actually utilizing an ICT. According to Alampay (2006a), there is a clear correspondence between these conceptual distinctions and Sen's concepts pertaining to capabilities and opportunities, freedoms, and functionings (See Figure 2.)

People's real opportunities for using ICTs are dependent on the infrastructure and means of access that are available in the communities they belong to (Alampay, 2006a). However, studies have shown that, even when ICTs are available, it does not necessarily mean people use them-just 
as it may happen that people are capable of using an ICT even though they have no access to them (Heeks, 2000). As such, aside the opportunities available for accessing ICTs, several surveys have looked at the capability for people to use the telephone, cell phone and the internet and the indirect ways for using them. More specifically, the capability to use different ICTs was measured according to two dimensions: first was the actual capability to use an ICT (landline phone, cell phone, etc) and second was how they were able to access the technology (Alampay, 2006a).

The capability to use ICT presupposes the presence or absence of an ICT device which is only a small part of the broader context of how people can actually use ICTs in their lives (Alampay, 2006a). It also involves, in a wider sense, people being able to use ICTs for personally or socially meaningful ends (Warschauer, 2004), whether they are capable of doing any functions on their own or whether they needed any assistance. Nevertheless, connected to capability to use were the barriers to use, especially for people who consider ICTs to be important in their daily lives.

Freedom can be defined in terms of people's preferences and perceived value of ICTs (Alampay, 2006a). This is because individual choices to use a basic commodity can be affected by a person's perceived value of the good. However, motivation or value of using ICTs could be based on people's perception of how it can be used or affect their lives, whether at home or at work, and whether positively or negatively (Heeks, 2000).

Realised Functionings was operationalised as recent use of ICTs i.e. people's use of ICTs and their purpose for using them.

\section{Method}

The study adopted the survey design approach. The locations were a rural (Erunmu) and an urban (Bodija) area in Ibadan, a Nigerian munic ipality. Erunmu community is located in Egbeda Local Government Area of Oyo state, Nigeria with a population size of about two thousand people who are mainly adults. The area consists of 5 wards (Egbeda, LGA 2008). Erunmu's population is made up of men, women, youths and children whose occupation is mainly farming, trading, and schooling. Their literacy level is low. Bodija community is located in Ibadan North area of Oyo State, Nigeria. It is populated by men, women (both old and young), that are elites and middle class citizens whose level of education is very high (i.e. most of them are professionals-high class people e.g. bankers, teachers, accountants, telecommunication experts, students etc). According to the 2006 national population census figures (National Population Commission of Nigeria, 2006), the estimated population of Bodija is 15,800 with the following five areas making up the community - Osuntokun, Are, Favos, Awolowo and Customs. In selecting the two survey locations, cons iderations were made about the opportunities to access ICT - availability of and access to internet services; cybercafés; public calling offices and public phones; cell sites and cell phone service; etc

The two study locations were intentionally selected with a view to ensuring rural versus urban data comparisons. The respondents in the randomly selected households were chosen purposively, alternating between father, mother and other members of the household older than twelve to ensure a balance across gender and age. In this sense, cluster sampling was used in both areas, since the population in each of the locations was partitioned into clusters. This method is commonly recommended for efficiency, although it does sacrifice some accuracy given that some sampling error can occur at each sampling stage (Babbie, 2000).

Data was collected with a structured questionnaire. It contained a mixture of open and close ended questions structured into four sections: Section A requested the respondents' demographic information, while Section B to D contained questions that were based on the research questions such as ownership, form of access and use of ICT, ICT facilities that they were capable of using, 
frequency and purpose of use, work type, reasons for using ICTs and barriers to the use of ICTs. The questionnaire was examined by experts in gender and ICT studies and their comments were used to arrive at the final version. The Cronbach alpha reliability co-effic ient of $\alpha=0.71$ was achieved. The questionnaire was administered to two hundred respondents in Erunmu and three hundred in Bodija. Copies of the questionnaire were given to different categories of people such as teachers, artisan, traders, professionals, women, men etc in the two locations to capture all shades of opinions. The researcher and four (4) survey interviewers ( 2 from each area) collected data personally. Collected data were structured into grouped frequency distributions. Chi-square analys is was used to determine the significant factors that affect people's access and use of ICTs.

\section{Results}

\section{Demographic Characteristics of the Respondents}

\section{Erunmu}

The 200 respondents in Erunmu were split between men and women (young and old), 80 and 120 respectively. Some of the respondents had some high school education (50\%), while $45 \%$ belonged in households with incomes less than N10, 000 per month. 32.5\% of the respondents were farmers/fishermen and the highest education attained by the respondents was University but many of them had the National Certificate of Education (NCE).

\section{Bodija}

In terms of gender, we surveyed more males than females most of whom were business men/women followed by public/civil servant and private workers. The highest household income collected monthly falls between N10, 000-N50, 000 and the highest education attained was university level qualification (refer to Table 1).

Table 1: Demographic Characteristics of Respondents

\begin{tabular}{|c|c|c|}
\hline CHARACTERISTIC & ERUNMU (RURAL) & BODIJA (URBAN) \\
\hline $\begin{array}{ll}\text { Sex: } & \text { Male } \\
& \text { Female }\end{array}$ & $\begin{array}{l}80(40 \%) \\
120(60 \%)\end{array}$ & $\begin{array}{l}160(53 \%) \\
140(46 \%)\end{array}$ \\
\hline $\begin{array}{ll}\text { Age: } & 20-30 y \mathrm{rs} \\
\text { (in years) } & 31-40 \mathrm{yrs} \\
& 41-50 \mathrm{yrs} \\
& 51-60 \mathrm{yrs} \\
\end{array}$ & $\begin{array}{c}50(25 \%) \\
39(19.5 \%) \\
80(40 \%) \\
31(15.5 \%) \\
\end{array}$ & $\begin{array}{c}90(30 \%) \\
90(30 \%) \\
55(18.3 \%) \\
65(21.6 \%) \\
\end{array}$ \\
\hline $\begin{array}{l}\text { Single } \\
\text { Married } \\
\text { Divorced } \\
\text { Widowed } \\
\end{array}$ & $\begin{array}{l}50(25 \%) \\
80(40 \%) \\
40(20 \%) \\
30(15 \%) \\
\end{array}$ & $\begin{array}{l}70(23 \%) \\
120(40 \%) \\
60(20 \%) \\
50(17 \%) \\
\end{array}$ \\
\hline $\begin{array}{ll}\text { Education } & \text { Primary } \\
\text { (highest attained) } & \text { Secondary } \\
& \text { T.T.E } \\
& \text { NCE } \\
& \text { Polytechnic } \\
& \text { University } \\
& \text { Others }\end{array}$ & $\begin{array}{l}20(10 \%) \\
20(10 \%) \\
30(15 \%) \\
60(30 \%) \\
50(25 \%) \\
20(10 \%) \\
---\end{array}$ & $\begin{array}{c}--- \\
65(21.6 \%) \\
25(8.3 \%) \\
10(4 \%) \\
80(26 \%) \\
120(40 \%)\end{array}$ \\
\hline $\begin{array}{lc}\text { Household } & <\mathrm{N} 10,000 \\
\text { Income } & \mathrm{N} 10,000-\mathrm{N} 50,000 \\
& \mathrm{~N} 50,000-\mathrm{N} 100,000 \\
& \mathrm{~N} 100,000 \& \text { above } \\
\end{array}$ & $\begin{array}{l}90(45 \%) \\
80(40 \%) \\
30(15 \%) \\
--- \\
\end{array}$ & $\begin{array}{c}10(3.3 \%) \\
120(40 \%) \\
160(53.1 \%) \\
10(3.3 \%) \\
\end{array}$ \\
\hline
\end{tabular}




\begin{tabular}{||ll|c|c||}
\hline \hline Type & Public/Civil Servant & $20(10 \%)$ & $80(26 \%)$ \\
of & Private sector & $05(2.5 \%)$ & $70(23.3 \%)$ \\
Work & Housewife & $40(20 \%)$ & $10(4 \%)$ \\
& Business man/woman & $40(20 \%)$ & $100(33.3 \%)$ \\
& Farmer/Fisherman & $65(32.5 \%)$ & --- \\
& Housekeeper & $10(\%)$ & $10(4 \%)$ \\
& Artisan & $20(10 \%)$ & $30(10 \%)$ \\
Others & --- & -- \\
\hline
\end{tabular}

\section{Ownership, Access and Capability to use ICTs}

In terms of ICT ownership, the survey revealed that the most common ICTs in Erunmu homes were television and radio. Cel1/mobile phone ownership came third. In Bodija homes however, radio and cell/mobile phone came first, followed by the television and computer with internet services. Most respondents in Bodija indicated having the landline telephone previously but at present, only fifty of them indicated having it. In Erunmu ten respondents indicated having the landline phones because it is believed to be cheaper.

Table 2: ICT ownership

\begin{tabular}{|l|c|c|}
\hline \multicolumn{1}{|c|}{ ICT facilities } & $\begin{array}{c}\text { Erunmu } \\
\text { who own }(\mathbf{n = 2 0 0})\end{array}$ & $\begin{array}{c}\text { Bodija } \\
\text { who own }(\mathbf{n}=\mathbf{3 0 0})\end{array}$ \\
\hline Radio & 180 & 300 \\
\hline Television & 200 & 290 \\
\hline Cell/Mobile Phone & 100 & 300 \\
\hline Landline telephone & 10 & 50 \\
\hline Cable TV/ DSTV & 0 & 80 \\
\hline Personal Computer & 05 & 80 \\
\hline Computer with Internet services & 0 & 100 \\
\hline Total=n (Respondents) & 495 & 1200 \\
\hline
\end{tabular}

Most ICT facilities that respondents in Erunmu do not have access to were: Cable TV, personal computer and computer with internet facilities but they indicated using these facilities in churches and cyber cafés. But in Bodija community cyber cafés and public places (as the library, games places) were the other places of access to the ICT facilities. About 30\% of them use the facilities in their working places or friends' houses but alternative places of access and use of cell phones and landline telephones were call centres.

\section{Capability to use ICTs}

Despite more people owning cell/mobile phones than landline telephones, more respondents reported being capable of using the landline phones more than the cell phones. Also, not everyone who knew how to use the computer was capable of browsing the internet. Only fifty respondents chose "capable of using the computer with internet services" in Erunmu, about 90 chose" capable of using it with the help of someone else" while the rest sixty respondents chose "not capable". The same was also reported about cable TV/DSTV, where (120) respondents chose capable of using it with the help of someone else. Overall, there was a higher proportion of those sampled in Bodija who were capable of using all these ICT facilities than in Erunmu (refer to Table 3). 
Table 3: Capability to use ICTs

\begin{tabular}{|l|c|c|}
\hline \multicolumn{1}{|c|}{ ICT } & $\begin{array}{c}\text { No capable in } \\
\text { Erunmu (n=200) }\end{array}$ & $\begin{array}{c}\text { No. capable in } \\
\text { Bodija (n=300) }\end{array}$ \\
\hline Radio & 200 & 300 \\
\hline Tele vision & 200 & 300 \\
\hline Cell/Mobile phone & 80 & 280 \\
\hline Landline telephone & 100 & 250 \\
\hline Cable TV/DSTV & 20 & 180 \\
\hline Personal computer & 70 & 200 \\
\hline Computer with Internet browsing & 50 & 150 \\
\hline $\begin{array}{l}\text { Internet search using search en- } \\
\text { gines }\end{array}$ & 30 & 150 \\
\hline Total=n (Respondents)= & 750 & 1810 \\
\hline
\end{tabular}

Aside from looking at the capability of the people in general, the capability to use different ICT facilities was also cross-tabulated against gender; location (Erunmu [rural] and Bodija [urban]); level of education; age; and household income. The results are presented in Tables 4 and 5.

Table 4: Percentage capable of using ICTs in Erunmu

\begin{tabular}{|c|c|c|c|c|c|c|}
\hline Variable & $\begin{array}{l}\text { Valid Responses } \\
\text { (n) }\end{array}$ & $\begin{array}{l}\text { Landline } \\
\text { telephone }\end{array}$ & $\begin{array}{c}\text { Cell } \\
\text { phone }\end{array}$ & $\begin{array}{l}\text { Cable TV } \\
\text { /DSTV }\end{array}$ & $\mathrm{PC}$ & $\begin{array}{l}\text { Computer } \\
\text { with inter- } \\
\text { net }\end{array}$ \\
\hline Gender: & $\begin{array}{c}\text { Male } 80 \\
\text { Female } 120 \\
\text { Chi-Square }\end{array}$ & $\begin{array}{c}15.00 \\
35.00 \\
3.534\end{array}$ & $\begin{array}{c}30.00 \\
10.00 \\
2.122 \\
\end{array}$ & $\begin{array}{l}7.50 \\
2.50 \\
3.943\end{array}$ & $\begin{array}{c}21.50 \\
13.50 \\
1.755 \\
\end{array}$ & $\begin{array}{c}9.00 \\
6.00 \\
3.522 \\
\end{array}$ \\
\hline Education & $\begin{array}{lc}\text { Primary } & 20 \\
\text { Secondary } & 20 \\
\text { T.T.E } & 30 \\
\text { NCE } & 60 \\
\text { Polytechnic } & 50 \\
\text { University } & 20 \\
\text { Chi-square } & \end{array}$ & $\begin{array}{c}7.84 \\
9.91 \\
75.87 \\
95.00 \\
84.86 \\
78.33 \\
45.666^{* * *}\end{array}$ & $\begin{array}{c}14.00 \\
21.21 \\
83.33 \\
95.00 \\
91.67 \\
85.56 \\
42.875 * * *\end{array}$ & $\begin{array}{c}0.00 \\
0.90 \\
53.20 \\
80.00 \\
63.06 \\
76.67 \\
40.00 * * *\end{array}$ & $\begin{array}{c}0.00 \\
14.00 \\
98.48 \\
70.00 \\
70.00 \\
76.67 \\
68.88 * * *\end{array}$ & $\begin{array}{c}0.00 \\
18.18 \\
75.50 \\
85.00 \\
60.60 \\
65.56 \\
41.570 * * *\end{array}$ \\
\hline Age & $\begin{array}{lr}21-30 & 50 \\
31-40 & 39 \\
41-50 & 80 \\
51-60 & 31 \\
\text { Significance } \\
\text { Chi-Square }\end{array}$ & $\begin{array}{c}74.55 \\
85.56 \\
85.56 \\
73.77 \\
0.000 \\
12.5\end{array}$ & $\begin{array}{l}83.64 \\
76.67 \\
76.55 \\
47.54 \\
0.227 \\
33.25 \\
\end{array}$ & $\begin{array}{l}70.91 \\
81.11 \\
41.55 \\
22.95 \\
0.000 \\
26.60\end{array}$ & $\begin{array}{c}89.55 \\
84.21 \\
50.00 \\
9.77 \\
0.237 \\
33.496 \\
\end{array}$ & $\begin{array}{l}85.07 \\
80.70 \\
30.00 \\
15.23 \\
0.125 \\
20.00\end{array}$ \\
\hline $\begin{array}{l}\text { Hous ehold } \\
\text { Income }\end{array}$ & $\begin{array}{l}<\mathrm{N} 10000 \quad 90 \\
\text { N10000-N50000 } \\
\text { N51000-100000 } \\
\text { N100000\&above } \\
\text { Chi-Square }\end{array}$ & $\begin{array}{c}10.98 \\
59.00 \\
95.56 \\
0.00 \\
33.15^{* * *}\end{array}$ & $\begin{array}{c}30.91 \\
63.88 \\
95.55 \\
0.00 \\
23.45^{* *}\end{array}$ & $\begin{array}{c}30.00 \\
65.00 \\
92.00 \\
0.00 \\
20.00 * *\end{array}$ & $\begin{array}{c}12.22 \\
65.55 \\
80.00 \\
0.00 \\
33.36^{* * *}\end{array}$ & $\begin{array}{c}10.00 \\
70.00 \\
85.00 \\
0.00 \\
44.00 * * *\end{array}$ \\
\hline Overall & (Total) 200 & 88.30 & 75.88 & 66.87 & 55.55 & 65.00 \\
\hline
\end{tabular}

Note: T.T.E $=$ Teacher Training Education; NCE=National Certificate of Education 
Table 5: Percentage capable of using ICTs in Bodija

\begin{tabular}{|c|c|c|c|c|c|c|}
\hline Variable & $\begin{array}{l}\text { Valid Responses } \\
\text { (n) }\end{array}$ & $\begin{array}{l}\text { Landline } \\
\text { telephone }\end{array}$ & $\begin{array}{l}\text { Cell } \\
\text { phone }\end{array}$ & $\begin{array}{c}\text { Cable TV } \\
\text { /DSTV }\end{array}$ & $\mathrm{PC}$ & $\begin{array}{l}\text { Computer } \\
\text { with inter- } \\
\text { net }\end{array}$ \\
\hline Gender: & $\begin{array}{l}\text { Male } 160 \\
\text { Female } 140 \\
\text { Chi-Square }\end{array}$ & $\begin{array}{c}66.66 \\
75.55 \\
5.78\end{array}$ & $\begin{array}{c}92.66 \\
75.66 \\
6.33\end{array}$ & $\begin{array}{c}84.22 \\
60.76 \\
6.33\end{array}$ & $\begin{array}{c}86.67 \\
85.55 \\
5.99\end{array}$ & $\begin{array}{c}77.15 \\
73.22 \\
2.65\end{array}$ \\
\hline Education & $\begin{array}{lc}\text { Primary } & 0 \\
\text { Secondary } & 65 \\
\text { T.T.E } & 25 \\
\text { NCE } & 10 \\
\text { Polytechnic } & 80 \\
\text { University } & 120 \\
\text { Chi-square } & \end{array}$ & $\begin{array}{c}0.000 \\
68.48 \\
88.88 \\
88.90 \\
90.05 \\
98.88 \\
45.666^{* * *}\end{array}$ & $\begin{array}{c}0.000 \\
65.89 \\
85.65 \\
87.66 \\
89.50 \\
95.00 \\
42.875 * * *\end{array}$ & $\begin{array}{c}0.000 \\
60.68 \\
72.00 \\
77.88 \\
80.70 \\
90.99 \\
60.332 * * *\end{array}$ & $\begin{array}{c}0.000 \\
43.33 \\
70.00 \\
85.65 \\
98.88 \\
85.80 \\
67.655^{* * *}\end{array}$ & $\begin{array}{c}0.000 \\
77.60 \\
85.00 \\
85.00 \\
88.00 \\
77.66 \\
77.525^{* * *}\end{array}$ \\
\hline Age & \begin{tabular}{cc}
$21-30$ & 90 \\
$31-40$ & 90 \\
$41-50$ & 55 \\
$51-60$ & 65 \\
\multicolumn{2}{c}{ Significance } \\
\multicolumn{2}{c}{ Chi-Square }
\end{tabular} & $\begin{array}{l}77.36 \\
75.31 \\
73.53 \\
88.57 \\
0.176 \\
4.937 \\
\end{array}$ & $\begin{array}{c}73.68 \\
75.88 \\
77.56 \\
86.66 \\
0.000 \\
35.496 * * * \\
\end{array}$ & $\begin{array}{c}74.29 \\
90.60 \\
88.76 \\
70.70 \\
0.000 \\
65.063 * * * \\
\end{array}$ & $\begin{array}{c}88.88 \\
95.76 \\
88.55 \\
65.55 \\
0.000 \\
55.222 * * * \\
\end{array}$ & $\begin{array}{c}75.55 \\
86.88 \\
70.00 \\
87.00 \\
0.000 \\
42.925^{* * *} \\
\end{array}$ \\
\hline $\begin{array}{l}\text { Household } \\
\text { Income }\end{array}$ & $\begin{array}{l}<\mathrm{N} 10000 \quad 10 \\
\text { N10000-N50000 } \\
\text { N51000-100000 } \\
\text { N100000\&above } \\
\text { Chi-Square }\end{array}$ & $\begin{array}{c}788.57 \\
73.53 \\
85.66 \\
92.31 \\
38.444 * * *\end{array}$ & $\begin{array}{c}90.00 \\
55.88 \\
100.00 \\
98.50 \\
39.07 * * *\end{array}$ & $\begin{array}{c}85.55 \\
80.00 \\
80.00 \\
75.55 \\
23.08^{* * *}\end{array}$ & $\begin{array}{c}75.55 \\
97.00 \\
95.50 \\
95.87 \\
35.000 * * *\end{array}$ & $\begin{array}{c}72.00 \\
95.00 \\
87.77 \\
77.00 \\
33.94 * * *\end{array}$ \\
\hline Overall & (Total) 300 & 78.88 & 66.70 & 75.55 & 66.60 & 70.00 \\
\hline
\end{tabular}

Note: T.T.E = Teacher Training Education; NCE=National Certificate of Education

\section{Gender and Capability to use ICTs}

Results in Tables 4 and 5 revealed that in the two locations, the male respondents were capable of using all the ICTs (cell phone, Cable TV/DSTV, personal computer and computer with internet services) except landline telephone. What may account for the difference is the fact that the women sampled in the two locations were not as educated as the men. For example, in Erunmu, the highest educational level of few of the women was a National Certificate of Education (NCE). In Bodija, there were some women who had university education but because most married women often engage in domestic activities, they did not have adequate time to use the other ICTs except for landline telephone which is simpler to use. Thus, there was a gender digital divide in the two locations. What account for this might also be that more men were included in the sample in the two locations.

\section{Level of Education and Capability to use ICTs}

Respondents' level of education was a significant factor that determined the capability of people in both areas to use all the ICTs with those having less education being less capable. In Erunmu, it was noted that some of the respondents that had polytechnic level education were able to use cell phones and landline telephones more than the respondents that had university education (refer to Table 4). But in the use of personal computers and internet services, the respondents with university education could use them more than any other with a different education level. But the reverse is the case in Bodija where the respondents with university education were able to use landline telephone, cell phone, and cable TV/DSTV, but respondents with polytechnic level education were more capable of using personal computer and computer with internet services than 
those with university level education. This showed that the level of education was a significant factor that determined the capability of using ICTs.

\section{Age \& Capability to Use ICTs}

In both communities, the younger set of respondents was more capable of using most of the ICTs. One explanation for this could be the fact that the internet is a more recent development, and as such, only the younger segment of the population would have had the benefit of being exposed to it in school and in other places. The difference however, was not significant for their capability to use a telephone. Given that this was the result in both Erunmu and Bodija, this may, to a large extent, be a reflection of people's exposure to the telephone, which is a technology that had been in use for a much longer period, and not necessarily a reflection of greater access to it.

\section{Income Level \& Capability of Using ICTs}

Results in Tables 4 and 5 also revealed that household income level plays a significant role with respect to people's capability of using ICTs. But it was found in Bodija community that people earning N51, 000-N100, 000 could use cell phones more than those earning N100,000 and above whereas in Erunmu, the respondents earning N51, 000-N100, 000 were more capable of using all the surveyed ICTs than any other group. This showed that the income earned is a significant contributor to the capability of using ICTs.

\section{Actual Use of ICT Facilities (Realised Functionings)}

A question was posed to the respondents to indicate the mode of communication they use in communicating with different groups and situations. For friends/relatives all the people in Erunmu chose personal i.e. the 200 respondents, some of them still chose the usage of cell phones to communicate with the ir relatives. Few people chose the use of e-mail or the internet (refer to Table 6). Communicating with the ir work, banks, school, hospital, and organization was also personal. Whereas, Bodija respondents chose personal and cell phone for communicating w ith the ir relatives/friends, banks, work, school, hospital and organization. But the respondents in Bodija also communicated with the banks and school with their cell phones and e-mail more than Erunmu (refer to Table 7). However, it was reported that none of the respondents (i.e. in Erunmu and Bodija) communicated in any form with the government.

Also noticed was the fact that the respondents in both locations still preferred to communicate with the ir friends/re latives, work, banks, school, hospital, organization, and emergency through personal means, followed by the use of cell phones, internet or e-mail etc. They stated that before any personal contacts especially with friends, they have to get in touch with friends first with the use of cell phones or the internet before personal means. It could be inferred from the results that cell phones are still actually in use more than any other ICT facilities. 
Table 6: Actual Use of ICT facilities in Erunmu

\begin{tabular}{|c|c|c|c|c|c|c|}
\hline & Personal & Telephone & $\begin{array}{l}\text { Cell } \\
\text { phone }\end{array}$ & $\begin{array}{l}\text { Email or } \\
\text { internet }\end{array}$ & Others & None \\
\hline Relative & 200 & $\begin{array}{l}---- \\
\end{array}$ & 180 & 20 & $\begin{array}{ll}---- \\
\end{array}$ & ----- \\
\hline Work & 200 & $\begin{array}{l}---- \\
\end{array}$ & ----- & $\begin{array}{l}---- \\
--\end{array}$ & $\begin{array}{ll}---- \\
\end{array}$ & ----- \\
\hline Government & $\begin{array}{ll}---- \\
\end{array}$ & $\begin{array}{l}---- \\
\end{array}$ & $\begin{array}{ll}---- \\
\end{array}$ & $\begin{array}{l}---- \\
\end{array}$ & $\begin{array}{ll}---- \\
\end{array}$ & ----- \\
\hline Banks & 200 & $\begin{array}{l}---- \\
--1\end{array}$ & ----- & $\begin{array}{l}---- \\
--1\end{array}$ & ---- & ----- \\
\hline School & 200 & $\begin{array}{l}---- \\
--1\end{array}$ & ----- & $\begin{array}{l}---- \\
--\end{array}$ & ---- & ---- \\
\hline Hos pital & 200 & $\begin{array}{ll}---- \\
\end{array}$ & ----- & ----- & ----- & ---- \\
\hline Organization & 80 & $\begin{array}{l}---- \\
\end{array}$ & ----- & ----- & ----- & ----- \\
\hline Emergency & 150 & $\begin{array}{l}---- \\
\end{array}$ & ----- & ----- & ----- & ----- \\
\hline $\begin{array}{l}\text { Total=n (Respon - } \\
\text { dents })\end{array}$ & 1230 & ---- & ----- & ---- & ---- & ---- \\
\hline
\end{tabular}

Table 7: Actual Use of ICT facilities in Bodija

\begin{tabular}{|c|c|c|c|c|c|c|}
\hline & Personal & Telephone & $\begin{array}{l}\text { Cell } \\
\text { phone }\end{array}$ & $\begin{array}{l}\text { Email or } \\
\text { internet }\end{array}$ & Others & None \\
\hline Relative & 300 & 150 & 280 & 200 & $\begin{array}{l}---- \\
\end{array}$ & ---- \\
\hline Work & 300 & $\begin{array}{l}---- \\
\end{array}$ & $\begin{array}{l}---- \\
-\end{array}$ & $\begin{array}{l}---- \\
\end{array}$ & $\begin{array}{l}---- \\
--1\end{array}$ & $\begin{array}{l}---- \\
\end{array}$ \\
\hline Government & ----- & - & $\begin{array}{l}---- \\
--1\end{array}$ & ----- & ---- & $\begin{array}{l}---- \\
--\end{array}$ \\
\hline Banks & 300 & $\begin{array}{l}---- \\
\end{array}$ & 200 & 150 & ----- & ----- \\
\hline School & 300 & ----- & 180 & 140 & ----- & ----- \\
\hline Hos pital & 300 & $\begin{array}{l}---- \\
\end{array}$ & ---- & $\begin{array}{l}---- \\
\end{array}$ & ----- & ----- \\
\hline Organization & 280 & ----- & $\begin{array}{l}---- \\
\end{array}$ & $\begin{array}{l}---- \\
\end{array}$ & $\begin{array}{ll}---- \\
\end{array}$ & ---- \\
\hline Emergency & 250 & ----- & ----- & ----- & ----- & ---- \\
\hline $\begin{array}{l}\text { Total }=\text { n }(\mathrm{Re}- \\
\text { spondents })\end{array}$ & 2030 & ----- & ----- & ----- & ----- & ----- \\
\hline
\end{tabular}

\section{Discussion}

\section{Forms of Access to the ICT Facilities}

Forms of accessing ICT facilities by people depends on the people's functioning which can be realized or unrealized, depending on whether they are able to act on the things they consider valuable (Nussbaum, 2000). In respect to the form of access to ICTs, results showed the importance of identifying the ICTs which few households owned and had no access to at home because it was in such cases that public facilities for accessing the ICT services were most needed. The survey reveals the real opportunities that were available for the people in the two locations to access ICT, which were their homes, public places such as the church, work places, friends and cyber café. It also showed that the most common ICT facilities that the respondents in the two locations had were radio and television followed by cell/mobile phones. The ones they did not have were accessed in other places including public libraries, work places, churches, and cyber cafes. However, the lack of ownership did not prevent the respondents from accessing or using the ICT facilities. The importance of public facilities for accessing ICTs in this situation where the infrastructure is deficient or lacking in the homes was also illustrated by the results. Considering that no other public places were reported apart from the church, work, and cyber café, then, the primary use of cell phones, personal computer, cable TV/DSTV was through ownership, relatives and friends. This shows why it is important to survey households and determine the options they have for using ICTs (ITU, 2003). 


\section{Capability to Use ICTs}

The presence or absence of an ICT device is only a small part of the broader context of how people could actually use ICTs in their lives (Sen, 1999). It was noted by World Bank (1998) that the nature of capability to use ICTs is apparent that age, gender, income etc play significant role in the capability to use ICT facilities. Aside surveying the households, it was also important to know the capabilities of the respondents in us ing ICTs since Sen (1999, cited in Alampay, 2006a) noted that "social and economic factors ... are important not only on the ir own, but also for the role that they play in giving people the opportunity to approach the world with courage and freedom" (Alampay, 2006). In this sense, it is important to see how social and economic factors, such as private ownership of ICTs, basic education, age, income, etc factor determine peoples' capability to use ICTs:

It was noted in both locations that they were capable of using radio and the television (100\%) more than any other ICT facility. However, in Erunmu the respondents chose being able to use landline telephones more than the cell/mobile phones, compared to Bodija the urban area where the respondents also showed the ability to use cell phones more than the respondents in Erunmu. The reason for this is the higher level of education attained by the respondents in Bodija as against those in Erunmu. Cell/mobile phones were said to be more complex than landline telephones and because most respondents in Bodija were university graduates, they could handle cell phones than landline telephones. Also level of education had the strongest influence on the capability to use cell phones, personal computer and computer with internet services with the respondents having less education being more disadvantaged in us ing the facilities. The characteristics of the respondents who used ICT were mainly the educated people. This factor also explained the reasons for their capabilities of using some of the ICT facilities such as the cable TV/DSTV, personal computer, computer with internet services. Some studies have suggested that educational attainment has a stronger influence on home computer use than family income, while others identified family income to be a stronger predictor of home computer use. One study showed that "home computer use ranged from $18.9 \%$ for those with no high school degree to $81.9 \%$ for those holding graduate degrees" (Valletta \& MacDonald, 2003, p.1). DeBell and Chapman (2006) echoed these findings in their discovery that parental educational attainment directly and dramatically correlates with the percentage of K-12 students who used the internet in the ir own home: less than high school (17\%); high school credential (34\%); some college (48\%); bachelor's degree $(56 \%)$; and graduate education $(63 \%)$ (p. 26). U.S. Census data showed a similarly strong correlation with educational attainment and home internet access, but a slightly more powerful influence with regard to family income (cited in the previous paragraph): less than high school (20.2\%); high school graduate/GED (43.1\%); some college or associate's degree (62.6\%); bachelor's degree (76.8\%); and advanced degree (81.1\%) (Computer, 2005, p. 2).

Results equally revealed that female respondents in both locations were capable of using landline telephone more than any other ICT facilities, while the ir male counterparts were capable of using all the other ICTs. What may account for the difference is the fact that women in both locations were not as educated as the men. Although Alampay's study in the Philippines showed a contrary view that female in the country were more capable of using some of the ICT facilities such as cell phones, landline telephones, SMS. The annual Taulbee Survey reported by the Computing Research Association in Computing Research News showed the percentage of computer science and computer engineering degrees granted to women (Vesgo, 2007). The National Sc ience Foundation report, Women, Minorities, and Persons with Disabilities in Science and Engineering: 2004 (NSF 04-317), showed the percentage of women who received engineering degrees as a percentage of all recipients. According to Kirk (2008) while women degree recipients in computer science and engineering continued to make fairly steady progress, their numbers continued to grow slowly. They remain dramatically underrepresented in IT as compared to their numbers in the 
population as a whole. Another recent report showed that while the numbers of computer science majors at all levels of higher education has increased overall, there has also been a decline in the percentage of women and students of color at all levels. Of all computer science majors in the U.S., only $18.8 \%$ were women, $3.4 \%$ were African American, $3.6 \%$ are Hispanic, $21.7 \%$ were Asian/Pacific Islander (although this population was overrepresented, their percentage had still declined), and 0.4\% were Native American (Kirk \& Zander, 2004, p. 169). The finding about males capability to use all the other ICTs apart from landline telephones was supported by Ugwuegbu (2002) in Owerri village.

On the relationships between socio-demographic composition of the respondents and access and use of ICTs, findings revealed that in both areas, the youths were more capable of using most of the ICT facilities (i.e. between ages 21-40) especially in the aspect of surfing the internet. One explanation for this is the fact that the internet is a more recent development, and as such, only the younger segment of the population would have had the benefit of being exposed to it in their schools. This finding was supported by Alampay's study in the Philippines. Also, household income plays a very significant role with respect to people's capability to use ICTs, with those with lower income having less ownership and capability to use ICTs. This may be because it could not be afforded. It should be noted, as well, that income is not only related to people's capacity to own ICTs but that it is strongly connected with people's level of education. As such, income plays an integral part in two factors that significantly affect people's capability to use ICTs, namely: education and direct ownership of ICT facilities. This finding was supported by Alampay's (2006a) study and the International Telecommunication Union (ITU, 2003). One study showed that " $2.7 \%$ of families with incomes under $\$ 15,000$ own computers compared to $77.7 \%$ of families with incomes over $\$ 75,000$; and among all families with incomes under $\$ 35,000$ computer ownership of white families was three times that of African-American families and four times that of Hispanic families" (Kirk \& Zander, 2004, p. 171). A 2003 study showed the dramatic influence of family income on home internet access: under $\$ 25,000(30.7 \%)$, $\$ 25,000$ $\$ 39,999(57.3 \%), \$ 50,000-\$ 74,999(77.9 \%), \$ 75,000-\$ 99,999(85.8 \%)$, and $\$ 100,000$ or more (92.2\%). ("Computer," 2005, p. 2) Another study showed that the "usage rate was $21.1 \%$ for individuals with family income under $\$ 15,000$ per year and $79.6 \%$ for individuals with family income of at least $\$ 75,000$ per year" (Valletta \& MacDonald, 2003, p. 1). A more recent study in 2006 showed little change in these earlier data related to family income and percentage of home computer use: under $\$ 20,000$ (19\%), \$20,000-\$34,999 (32\%), \$35,000-\$49,999 (45\%), \$50,000$\$ 74,999(54 \%)$, and $\$ 75,000$ or more (66\%) (DeBell \& Chapman, 2006).

\section{Conclusions and Policy Implications}

This study established that there were socio-demographic differences in access and use of ICTs in the study area. Thus, there is gender digital divide, digital divide as a result of high versus low literacy, high income versus low income and rural urban divide. As far as education was concerned, it was important, not only with respect to gaining the needed skills to use ICTs, but also with respect to people's motivation to even use an ICT. It was also discovered that income was significantly related to the amount of education a person receives. Above all income level, level of education, age, gender could be seen as the key "individual differences" that impact the freedoms, capabilities and functionings that relate to ICTs as per Sen's model. To bridge this digital divide gap we recommend the following:

The government should help solve the problem of inadequate ICT infrastructure by for instance, ICT imports duty free so that a lot of people could be able to afford them. This no doubt will increase access to them in both rural and urban areas. Access to ICTs can lead to other opportunities and services such as education, health, e-commerce and e-government. ICT diffusion can improve work productivity of an employee, organization or country, including positively affecting 
its Human Development Index (Jain \& Mutula 2001, Labelle 2005). It can expand and speed up the transmission and reception of information that households consider crucial in accessing markets and getting in touch with other people. Public libraries could also be established in communities or Local Government area which well-equipped and functional ICT facilities as a measure of making residents in rural and urban communities to have access ICTs

In addition, access to information means access to power and as the findings revealed male respondents were able to use most of the ICTs than their women counterparts. This calls for a policy to bridge the gender digital divide. In Nigeria as in most developing countries, women are still excluded from the scheme of things with regard to ICTs because they are considered less beneficial to women than for men and women are not consulted during the phases of design, acquisition, and installation of ICT based system; the resulting systems are inappropriate for women's needs. Women are also treated as passive recipients of technology and are not consulted on policy matters. Because technology is generally associated with men and because women are generally relegated to non-technological professions, women face a psychological barrier when confronted with ICT, which may be a conduit for information that is partly sexist. In order to bridge the gender digital divide gap, policies that would increase the general/ICT literacy level of women, that would remove cultural inhibitions against women in the use of ICTs thereby increasing the ir freedom and those that would make women to be better represented in ICT policy issues need to be enunciated. Unless Nigerian women (both those in rural and urban communities) are made to participate better in cyberspace through appropriate policies, they will continue to be excluded from the opportunities offered by ICTs.

Finally, there is a need for the Nigerian government to educate its citizens in rural and urban communities about ICT. Such education would make the citizens develop an awareness of it, be provided with skills to know that information is useful in daily life, to be able to make decisions about the information that is useful, to obta in it in the ocean of available information, and to process and transform it into knowledge required for a specific purpose. According to Olatokun (2007), education is thus necessary in order to reduce exclusion and/or isolation due to lack of universal familiarity with and use of ICT, avoid discrimination on the basis of literacy, and access useful sources of information. With the right education enabled by the right polic ies, more people would be able to access and use ICTs.

\section{References}

Alampay, E. (2006a). Analyzing socio-demographic differences in the access \& use of ICTs in the Philippines using the capability approach. NCPA G, University of the Philippines.

Alampay, E. (2006b). Beyond access to ICTs: Measuring capabilities in the in formation society. International Journal of Education and Development using ICT, 2(3). Retrieved February 8, 2008 from http://ijedict.dec.uwi.edu/viewartic le.php?id=196

Babbie, E. (2000). The practice of social research (9th ed.). Wadsworth.

Black, T. R. (2002). Understanding social science research (2nd ed.). Sage Publications.

Benton Foundation. (1998). Losing ground bit by bit: Low-income communities in the information age. United States. Retrieved March 6, 2008 from http://www.d igitald ividenetwork.org

Carino, L. V. (2003). Increasing social access to basic service. In V. A. Bautista, M. C. P. Alfiler, D. R. Reyes \& P. D. Tapales (Eds.), Public administration in the Philippines: A reader (2nd Ed) (pp. 743771). National College of Public Ad min istration and Governance, University of the Philippines.

Choike Organization (2004). A rural access to ICT model that combines community-owned ICT enterprises with wireless technologies can create more empowering and sustainable initiatives. Retrieved January 4, 2008 from http://www.choike.org 
Colle, R. D., \& Roman, R. (2002). Gender as an access issue. Techknowlogia. July - September, p. 31.

DeBell, M., \& Chap man, C. (2006). Computer and internet use by students in 2003 (NCES 2006-065). U.S. Department of Education. Washington, DC: National Center for Education Statistics.

Dig ital Dividends. (2001). Digital dividends webpage on background to digital divide. Retrieved March 6, 2008 fro $\mathrm{m}$ http://www.d igitald ividend.org/

Doczi, M. (2000). ICTs and social and economic inclusion. Retrieved March 62008 from http://www.med.govt.nz/pbt/infotech/ictinclusion/ictinclusion.pdf

Heeks, R. (2000). Information systems for public sector management. Govern ment data: Understanding barriers to citizen access and use. Government Working Paper series No. 10, pp. 25-30 Institute for Develop ment Policy and Management, University of Manchester.

International Teleco mmun ications Union (ITU). (2003). World telecommunication development report: Access Indicators for the information society, pp. 12-30.

Jain, P., \& Mutula, S. M. (2001). Diffusing information technology in Botswana: A framework for vision 2016. Information Development, 17(4), 234-239.

Kirk, M. (2008). Gender and information technology: Moving beyond access to co-create global partnership. Hershey, PA: IGI Global.

Kirk, M. \& Zander, C. (2004). Narrowing the digital divide: In search of a map to mend the gap. Journal of Computing Sciences in Colleges, 20(2), 168 - 175.

Labelle, R. (2005). ICT policy formulation and e-strategy development: A comprehensive guidebook. UNDP-APDIP ICT4D Series. Elsevier.

Madhusudan, C. N. (2002). India's hole in the wall key to bridging the digital divide? TechKnowlogia, July to September, 38-40.

Moss, M. L. (2000). Why cities will thrive in the information age. ULI on the future: Cities in the 21 st century. Washington, DC: Urban Land Institute, pp. 3-5.

National Population Co mmission of Nigeria. (2006). 2006 population and housing census facts and figures. Retrieved September 172007 fro $\mathrm{m}$ http://www.population.gov.ng/facts andfigures 2006.ht ml

National Science Foundation. (2004). Women, minorities and persons with disabilities in science and engineering. Retrieved October 152008 from http://www.aag.org/healthydepartments/ed project data/AAG Diversityreport.pdf

Nussbaum, M. (2000). Women and human development. Cambridge: Cambridge University Press; pp. 5069.

Olatokun, W. M. (2007). Leverag ing governance in Africa through ICTs: So me policy directions. In: V. Ku mar \& A. K. Sinha (Eds.), Proceedings of National Conference on Information Technology: Present Practices and Challenges, organized by Asia-Pacific Institute of Management, New Delhi, August 31-September 1, pp. 724-743.

Organisation for Economic Co-operation and Development (OECD). (2007). Information and communication technologies: The growth and development of information and communication technologies. Measuring user-created content: Implications for the ICT access and use. Retrieved April 182008

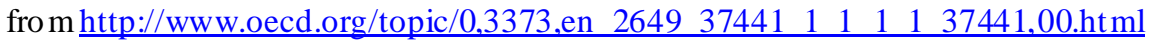

Robeyns, I. (2000). An unworkable idea or a promising alternative? Sen's capability approach reexamined. Working Paper - 28 November.

Robeyns, I. (2005). The capability approach: A theoretical survey. Journal of Human Development, 6(1): 93-114.

Sen, A. K. (1993). Capability and well-being. In M. Nussbaum \& A. K. Sen (Eds.), The quality oflife (pp. 5-10). Oxford: Clarendon Press. 
Sen, A. K. (1992). Inequality reexamined. Oxford: Clarendon Press; 1-50 pp.

Sen, A. K. (1987). The standard of living. Cambridge: Cambridge University Press.

Sen, A. K. (1987). Commodities and capabilities. Amsterdam: North Holland.

Sen, A. K. (1999). Development as freedom. New York: Knopf; pp. 1,10.

Sood, D. A. (2002). The center for knowledge societies: Guide to ICTs for development. Bangalore, 5pp.

Ugwuegbu, N. (2002). The Owerri digital village: A grassroots approach to bringing technology to Nigerian Youth for Technology Foundation Retrieved March 62008 from http://www.youthfortechnology.org

United Nations Economic and Social Commission for Asia and the Pacific (UNESCAP). (2005). Use of ICTs for achieving MDGS, the digital divide. Retrieved February 282008 from http://www.unescobkk.org/education/ict/online-resources/databases/ict-in-educationdatabase/article/?tx ttnews \%5Btt news \%5D $=1081 \& \mathrm{cHash}=8631 \mathrm{bbb} 6 \mathrm{e} 1$

United Nations Development Programme (UNDP) Evaluation Office. (2001). Information communication technology for development, No.5, 1-31pp.

Valletta, R., \& MacDonald, G. (2003). Is there a dig ital divide? FRBSF Economic Letter, Federal Reserve Bank of San Francisco, Issue 5, Dece mber 26.

Vesgo, J. (2007). Enrollments and degree production at US CS depart ments drop further in 2006-07. Computing Research News, 20(2).

Warschauer, M. (2004). Technology and social inclusion. Rethinking the digital divide. Cambridge Massachusetts: The MIT Press, 5-20pp.

World Bank. (1998). World development report 1988/99: Knowledge for development. The International Bank for Reconstruction and Development/The World Bank: Oxford University Press; 50pp.

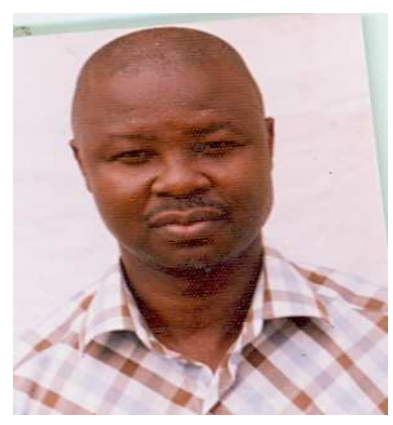

\section{Biography}

Dr. Wole Michael Olatokun obtained his Master and $\mathrm{PhD}$ degrees in Information Science from the University of Ibadan, Nigeria. He is currently a Senior Lecturer at the Department of Library and Information Studies, University of Botswana, Gaborone. His research interests include: National Information and Communication Technology (ICT) policy issues, Social informatics, Gender and ICT, eCommerce, eGovernment and Mobile Commerce, ICT adoption and application in different settings, and indigenous know ledge systems. He can be contacted by e-mail at: wole.olatokun@mopipi.ub.bw/woleabbeyolatokun@yahoo.co.uk 